\title{
Consensus recommendations on calf- and herd-level passive immunity in dairy calves in the United States
}

\author{
J. Lombard, ${ }^{1 *}+\oplus$ N. Urie, ${ }^{1} \oplus$ F. Garry, ${ }^{2} \oplus$ S. Godden, ${ }^{3} \oplus$ J. Quigley, ${ }^{4} \odot$ T. Earleywine, ${ }^{5} \odot$ S. McGuirk, ${ }^{6}$ \\ D. Moore, ${ }^{7} \odot$ M. Branan, ${ }^{1} \odot$ M. Chamorro, ${ }^{8}$ G. Smith, ${ }^{9} \odot$ C. Shivley, ${ }^{1}$ D. Catherman, ${ }^{10}$ D. Haines, ${ }^{11}$ \\ A. J. Heinrichs, ${ }^{12}$ (D) R. James, ${ }^{13}$ J. Maas, ${ }^{14}$ (D) and K. Sterner ${ }^{15}$ \\ ${ }^{1}$ USDA-Animal and Plant Health Inspection Service-Veterinary Services, Center for Epidemiology and Animal Health, \\ National Animal Health Monitoring System, Fort Collins, CO 80526-8117 \\ ${ }^{2}$ Department of Clinical Sciences, College of Veterinary Medicine and Biomedical Sciences, Colorado State University, Fort Collins 80523-1678 \\ ${ }^{3}$ Department of Veterinary Population Medicine, College of Veterinary Medicine, University of Minnesota, St. Paul 55108 \\ ${ }^{4}$ Cargill Animal Nutrition, Brookville, $\mathrm{OH} 45309$ \\ ${ }^{5}$ Land O'Lakes Animal Milk Solutions, Cottage Grove, WI 53527 \\ ${ }^{6}$ School of Veterinary Medicine, University of Wisconsin, Madison 53706 \\ ${ }^{7}$ Department of Veterinary Clinical Sciences, College of Veterinary Medicine, Washington State University, Pullman 99164 \\ ${ }^{8}$ Department of Clinical Sciences, College of Veterinary Medicine, Auburn University, Auburn, AL 36849 \\ ${ }^{9}$ Department of Population Health and Pathobiology, North Carolina State University, Raleigh 27607 \\ ${ }^{10}$ Strauss Feeds, Watertown, WI 53908 \\ ${ }^{11} \mathrm{SCCL}$, Saskatoon, Saskatchewan, Canada, 57K 6A2 \\ ${ }^{12}$ Department of Animal Science, The Pennsylvania State University, University Park 16802 \\ ${ }^{13}$ Down Home Heifer Solutions, Blacksburg, VA 24060 \\ ${ }^{14}$ School of Veterinary Medicine, University of California, Davis 95616 \\ ${ }^{15}$ Sterner Veterinary Clinic P.C., Ionia, MI 48846
}

\begin{abstract}
Passive immunity in calves is evaluated or quantified by measuring serum or plasma IgG or serum total protein within the first $7 \mathrm{~d}$ of age. While these measurements inform about circulating concentrations of this important protein, they are also a proxy for evaluating all of the additional benefits of colostral ingestion. The current individual calf standard for categorizing dairy calves with successful passive transfer or failure of passive transfer of immunity are based on serum IgG concentrations of $\geq 10$ and $<10 \mathrm{~g} / \mathrm{L}$, respectively. This cutoff was based on higher mortality rates in calves with serum $\operatorname{IgG}<10 \mathrm{~g} / \mathrm{L}$. Mortality rates have decreased since 1991, but the percentage of calves with morbidity events has not changed over the same time period. Almost $90 \%$ of calves sampled in the USDA National Animal Health Monitoring System's Dairy 2014 study had successful passive immunity based on the dichotomous standard. Based on these observations, a group of calf experts were assembled to evaluate current data and determine if changes to the passive immunity stan-
\end{abstract}

Received November 24, 2019

Accepted March 16, 2020.

*Current affiliation: USDA Animal and Plant Health Inspection Service-Veterinary Services, Field Operations, Field Epidemiology Investigation Services, Fort Collins, CO 80526-8117.

†Corresponding author: Jason.E.Lombard@usda.gov dards were necessary to reduce morbidity and possibly mortality. In addition to the USDA National Animal Health Monitoring System's Dairy 2014 study, other peer-reviewed publications and personal experience were used to identify and evaluate potential standards. Four options were evaluated based on the observed statistical differences between categories. The proposed standard includes 4 serum IgG categories: excellent, good, fair, and poor with serum IgG levels of $\geq 25.0$, 18.0-24.9, 10.0-17.9, and $<10 \mathrm{~g} / \mathrm{L}$, respectively. At the herd level, we propose an achievable standard of $>40$, 30,20 , and $<10 \%$ of calves in the excellent, good, fair, and poor categories, respectively. Because serum IgG concentrations are not practical for on-farm implementation, we provide corresponding serum total protein and \%Brix values for use on farm. With one-third of heifer calves in 2014 already meeting the goal of $\geq 25$ $\mathrm{g} / \mathrm{L}$ serum IgG at $24 \mathrm{~h}$ of life, this achievable standard will require more refinement of colostrum management programs on many dairy farms. Implementation of the proposed standard should further reduce the risk of both mortality and morbidity in preweaned dairy calves, improving overall calf health and welfare.

Key words: colostrum, passive immunity, morbidity, standard

\section{INTRODUCTION}

Calves are born without immunoglobulins because the cotyledonary synepitheliochorial placenta of the bovine, 
which is composed of 3 maternal and 3 fetal layers, does not allow immunoglobulins to transfer from dam to calf (Peter, 2013). Ingestion of colostrum is necessary for calves to acquire $\operatorname{IgG}$ and other immune factors. The ingestion of colostrum and transfer of immunoglobulins into the blood of the calf has been termed "passive transfer of immunity" or more recently "transfer of passive immunity." The former is more commonly used but the latter is technically more correct because immunoglobulin is not passively transferred but the immunity derived from colostrum ingestion is passive.

Transfer of passive immunity (TPI) is evaluated or quantified by measuring calf serum or plasma $\operatorname{IgG}$ or total protein. Although these measurements are informative about circulating concentrations of this important protein, they are also a proxy for evaluating the additional benefits of colostral ingestion, such as non-immunoglobulin immune factors, high nutrient intake, fluid provision, and warmth. High circulating $\mathrm{IgG}$ concentration in a calf is achieved by consumption of high-quality colostrum in high volume very soon after birth. Calves with high circulating IgG have also accrued these other benefits postnatally. For these reasons serum IgG concentration is an excellent predictor of lower morbidity and mortality.

The current individual calf standard for categorizing dairy calves with successful passive immunity (SPI) or failure of passive immunity (FPI) has been used for more than 35 yr (Gay, 1983). Serum IgG concentrations of $\geq 10 \mathrm{~g} / \mathrm{L}$ (SPI) and $<10 \mathrm{~g} / \mathrm{L}$ (FPI) define this dichotomous standard when dairy heifer calves are sampled within 1 to $7 \mathrm{~d}$ of age. This cutoff was based on numerous studies showing preweaned heifer calves with FPI were associated with higher mortality rates than calves with SPI (USDA, 1994; Wells et al., 1996; Weaver et al., 2000). The study by Urie et al. (2018b) showed a significant reduction in mortality for calves with serum IgG concentrations of $\geq 15 \mathrm{~g} / \mathrm{L}$ compared with calves with less than $15 \mathrm{~g} / \mathrm{L}$. However, recent studies have described reduced morbidity in calves to be associated with serum IgG levels higher than what has been traditionally recommended (Furman-Fratczak et al., 2011; Windeyer et al., 2014; Urie et al., 2018b).

Information on passive immunity and associations with morbidity and mortality for male dairy calves is not readily available for the United States or Canada. Two studies reported that colostrum management differs between heifer and bull calves, with bull calves generally receiving a lower volume of colostrum and having a lower serum total protein (Shivley et al., 2019; Renaud et al., 2020). No morbidity estimates were reported in these studies.
Transfer of passive immunity data from the beef industry provide a useful comparison to the dairy industry. The beef industry relies almost entirely on the calf to suckle colostrum from the dam without any human intervention. Studies have linked poor TPI in beef calves to increased morbidity and mortality and decreased weight gain (Wittum and Perino, 1995; Dewell et al., 2006). Studies suggest that IgG thresholds higher than what has been traditionally recommended in dairy calves are associated with improved health in beef calves. Beef calves with serum IgG concentrations $>24$ $\mathrm{g} / \mathrm{L}$ have a significant decrease in preweaning morbidity; in contrast, beef calves with IgG concentrations $<24 \mathrm{~g} / \mathrm{L}$ are 1.6 times more likely to become ill and have increased odds of preweaning morbidity (Waldner and Rosengren, 2009). Protection against disease was seen with increasing serum $\operatorname{IgG}$ values up to $32 \mathrm{~g} / \mathrm{L}$ and beef calves with serum IgG levels above $27 \mathrm{~g} / \mathrm{L}$ also weighed $3.35 \mathrm{~kg}$ more at $205 \mathrm{~d}$ of age than calves with lower serum IgG concentrations (Dewell et al., 2006). A study from Ireland (Todd et al., 2018) determined that optimal cut-offs to minimize disease and death in beef calves were serum IgG concentrations of 26 to $40 \mathrm{~g} / \mathrm{L}$ and total protein concentrations 6.0 to $6.3 \mathrm{~g} / \mathrm{dL}$. A comparison of morbidity and mortality between preweaned beef and dairy calves is not completely straightforward because beef calves are generally weaned around 6 mo of age (USDA, 2008), whereas dairy heifer calves are weaned around 9 wk of age (USDA, 2016). In both beef and dairy calves, however, morbidity and mortality is highest the first 6 wk of age (USDA, 2010; Urie, et al., 2018b). Based on the data available in beef calves, in addition to published studies of dairy calf health, the traditional thinking that the ideal TPI threshold for IgG is $\geq 10 \mathrm{~g} / \mathrm{L}$ appears to be inaccurate.

Education and training of dairy producers has improved colostrum management over the last 3 decades and now almost $90 \%$ of Holstein Friesian calves meet the current industry standard (Shivley et al., 2018). The percentage of all dairy heifer calves with FPI has decreased from $41 \%$ in 1991 (USDA, 1993) to $13.0 \%$ in 2014 (Urie et al., 2018a). Since 1996, preweaned dairy heifer mortality has decreased from $10.8 \%$ to $6.4 \%$ (USDA, 1996, 2018), whereas the average age at weaning has remained close to $8.5 \mathrm{wk}$.

Implementation of the current standard for PI has reduced preweaned calf mortality but preweaned calf morbidity has not declined significantly; $36.1 \%$ of preweaned heifer calves were reported to have scours or respiratory disease in 1991 compared with $33.1 \%$ in 2014 (USDA, 1994, 2018; Figure 1). Additionally, a recent study demonstrated a negative association between 




Figure 1. Morbidity and mortality estimates for preweaned dairy heifer calves from the National Animal Health Monitoring System (NAHMS) Dairy studies (USDA, 1994, 1996, 2018).

serum IgG and morbidity levels in dairy calves (Urie et al., 2018b). These data support increasing the level of TPI threshold since the current standard has not led to a reduction in dairy calf morbidity.

Although the individual calf-level standard has been widely adopted, different herd level standards have been promoted (the late J. W. Tyler, Veterinary Clinical Sciences, University of Missouri, Columbia, personal communication, 2002; McGuirk, 2005) but the level of adoption for this formerly proposed standard is unknown. As dairies move to a more population-oriented approach to managing their operations, an evaluation of the colostrum management program should be based on all calves and not on individuals. A herd-level standard is necessary to provide herd owners and personnel the targets necessary for improving calf health.

Considering that improvements in dairy calf morbidity have not paralleled improvements in colostrum management and mortality, a group of calf experts (i.e., authors) were assembled to review the available data and consider revising the individual calf TPI standard and developing a herd-level standard. This expert group considered data from the National Animal Health Monitoring System (NAHMS) Dairy 2014 Calf Component (Urie et al., 2018a), other published literature, and their own experiences. The objectives of this study were to evaluate different threshold values for TPI and their relationship to mortality and morbidity using available data and come to consensus on a calfand herd-level TPI standard. A secondary objective was to provide colostral management recommendations to meet the consensus standards.

\section{MATERIALS AND METHODS}

In the spring of 2018, the primary author convened a conference call with various academic, extension, and industry specialists working in the calf health arena to discuss the evaluation and possible revision of the TPI standards for dairy calves. On the first call, option 2 below was proposed as a starting point for discussion. Four conference calls were held where data from the NAHMS Dairy 2014 Calf Component (Urie et al., 2018a,b), other publications, and personal experiences were discussed.

The NAHMS Dairy 2014 Calf Component data were used to determine the relationship between serum IgG concentration and morbidity and mortality (Urie et al., 2018b). The Calf Component survey evaluated dairy heifer calves from birth to weaning. Colostrum management practices, including source, amount fed, and timing of colostrum administration were collected from each enrolled calf. Colostrum samples were collected and tested for IgG concentration. Blood was collected from heifer calves within $7 \mathrm{~d}$ of age and tested for serum IgG, serum total protein, and \%Brix. Any health condition, including scours, pneumonia, or lethargy, observed by calf caretakers was recorded as a morbidity event. Calves that died after colostrum administration and before weaning were counted as mortality cases. 
More detailed information on the NAHMS 2014 Calf Component is reported in Urie et al. (2018a,b).

For evaluation of a new standard, the original data set was modified. Calves where blood was collected at $<24 \mathrm{~h}$ of birth or after $7 \mathrm{~d}$ of age were excluded and those with serum IgG concentration of $<1 \mathrm{~g} / \mathrm{L}$, total protein concentration $>11 \mathrm{~g} / \mathrm{dL}$, and Brix score $>15 \%$ were considered outliers and excluded in all analyses. For this TPI analysis, calves fed colostrum replacer or colostrum supplement were also excluded.

A total of 4 options were evaluated: 2 options with 3 categories, one with 4 , and one with 5 categories, which are presented below:

$$
\begin{aligned}
& \text { (option } 1)<10.0 \mathrm{~g} / \mathrm{L}, 10.0 \text { to } 19.9 \mathrm{~g} / \mathrm{L}, \geq 20.0 \mathrm{~g} / \mathrm{L}, \\
& \text { (option } 2)<10.0 \mathrm{~g} / \mathrm{L}, 10.0 \text { to } 24.9 \mathrm{~g} / \mathrm{L}, \geq 25.0 \mathrm{~g} / \mathrm{L},
\end{aligned}
$$$$
\text { (option 3) <10.0 g/L, } 10.0 \text { to } 17.9 \mathrm{~g} / \mathrm{L} \text {, }
$$$$
18.0 \text { to } 24.9 \mathrm{~g} / \mathrm{L}, \geq 25.0 \mathrm{~g} / \mathrm{L},
$$$$
\text { (option 4) }<10.0 \mathrm{~g} / \mathrm{L}, 10.0 \text { to } 14.9 \mathrm{~g} / \mathrm{L} \text {, }
$$

15.0 to $19.9 \mathrm{~g} / \mathrm{L}, 20.0$ to $24.9 \mathrm{~g} / \mathrm{L}, \geq 25.0 \mathrm{~g} / \mathrm{L}$.

These 4 options were proposed as a starting point for discussion among the authors. Once there was agreement on evaluation of these options, then the statistical analysis subsequently described was conducted. The rationale for these proposed categories was based on the literature and expert opinion of the authors.

Descriptive data were analyzed using the PROC FREQ procedure in SAS (version 9.4, SAS Institute Inc., Cary, NC) and a chi-square test statistic was calculated to compare the different categories in the 4 options above. A $P$-value $<0.05$ was considered significant; however, the Bonferroni correction was applied to account for the multiple comparisons being made. The $P$-value of 0.05 was divided by the number of comparisons being made to determine the Bonferroni corrected $P$-value (Schaffer, 1995). PROC GENMOD was used to model predicted morbidity and mortality, at different cutoffs, using farm as the random effect along with previously identified predictor variables (Urie et al., 2018b). Additionally, PROC GLM was used to model equivalent serum total protein values and serum Brix scores for each proposed serum IgG category.

To evaluate the time in days to morbidity and mortality events for preweaned heifer calves, Kaplan-Meier survival graphs were constructed using the LIFETEST procedure in SAS. The STRATA statement was used to visualize differences based on serum IgG level, serum total protein level, and serum Brix percent. The log-rank test was used to evaluate differences of the survival curves throughout the preweaning period (Hosmer and Lemeshow, 1999) for each serum measurement. Censored calves were calves that were weaned before $60 \mathrm{~d}$ of age.

Logistic regression random effect models were constructed in SAS with predicted morbidity and mortality as outcomes as described by Urie et al. (2018b). Predicted morbidity included farm as a random variable and was adjusted for birth BW, housing ventilation, and average THI during the preweaning period. Predicted mortality included farm as a random effect and was adjusted for morbidity, birth weight, and amount of fat in the liquid diet per day (Urie et al., 2018b). Serum IgG was plotted against percent morbidity and mortality to visualize the relationship between $\operatorname{Ig} G$ and health events.

During discussions of the options the authors noted that some beef studies had proposed and used a cutoff of $24.0 \mathrm{~g} / \mathrm{L} \mathrm{IgG}$ (Dewell et al., 2006; Waldner and Rosengren, 2009). It is generally recognized/assumed that dairy calves are raised in more intense confinement conditions and exposed to more pathogens than their beef counterparts. With this in mind, the group felt strongly that passive immunity standards for the dairy industry should be equal to or higher than standards that are recommended in the beef industry, assuming that the analysis supported that conclusion. Ideally, the dairy and beef industry would have the same goals relative to TPI categories for both male and female calves.

Option 1 was eliminated because the highest cutpoint of $20.0 \mathrm{~g} / \mathrm{L} \mathrm{IgG}$ was low with respect to mean serum IgG in recent dairy studies and a cutoff that was associated with decreased morbidity in beef studies (Dewell et al., 2006; Waldner and Rosengren, 2009). For option 2 , some of the authors recognized differences in the performance and health of calves with a serum IgG of 12 to $14 \mathrm{~g} / \mathrm{L}$ versus those with values of 22 to $24 \mathrm{~g} / \mathrm{L}$; additionally, the authors viewed the 10.0 to $24.9 \mathrm{~g} / \mathrm{L}$ category as too wide and did not differentiate the risks associated with being in the lower end of the category versus the upper end. Option 3 was thought to categorize calves into reasonably different risk groups but there was concern about having 4 categories as opposed to the 2 for the current standard. Option 4 also placed calves into well-proportioned and reasonable categories but many felt the 5 different levels were complex and the ranges of the categories were too narrow. On the basis of NAHMS TPI data and previous studies, option 3 was selected for further analysis and discussion.

To provide evidence for the proposed categories of IgG concentration, we used a Bayesian change point method described by Barry and Hartigan (1993). This 
theory is implemented in the $\mathrm{R}$ package bcp, information on which can be found in Erdman and Emerson (2007). The method partitions the space along the variable on which change points are assessed into $U_{1}, U_{2} \ldots$, $U \mathrm{n}$ and an MCMC algorithm is used to determine the points between which there are substantial differences from the previous to the next point (where "substantial difference" is proportional to the ratio of the within and between sums of squares of the variable at the 2 points).

The following steps were taken to implement the method included the following for morbidity and mortality separately. (1) The rates of morbidity/mortality for calves with the same (rounded) whole-number IgG concentration were calculated. (2) Data sorted in order of IgG concentration (this implies a change at the same point in the sorted list of IgG concentrations). (3) The Barry and Hartigan (1993) method was used to find the posterior distributions for the probabilities of change points at each whole-number $\operatorname{IgG}$ concentration. (4) Finally, we narrowed the search for change points to the interval between $8 \mathrm{~g} / \mathrm{L} \mathrm{IgG}$ (slightly below the industry standard of $10 \mathrm{~g} / \mathrm{L}$ ) and $30 \mathrm{~g} / \mathrm{L}$ (slightly greater than the expert-elicited top-end value of $25 \mathrm{~g} / \mathrm{L}$ ) and found the IgG concentrations that exceeded the 80th percentile of the posterior probabilities of there being a change point at those $\operatorname{IgG}$ concentrations. This range (8-30 g/L) was also the most populated, and the number of observations above $30 \mathrm{~g} / \mathrm{L}$ were sparse.

Discussions of a herd-level standard were also based on evaluation of the NAHMS TPI data set. Specifically, whatever new goals were to be recommended, they needed to be realistic and achievable by commercial dairy herds. In other words, a reasonable proportion of calves within a reasonable proportion of herds must be able to reach the highest level for serum IgG. The NAHMS data provided the proportion of herds in the study meeting the recommended standards to determine if the standards were realistic and achievable.

The amount of colostral IgG fed to calves in the NAHMS TPI data set was determined by taking the number of liters fed at first feeding and multiplying by the $\operatorname{IgG}$ concentration of the sample. For subsequent feedings in the first $24 \mathrm{~h}$, the operation average colostral IgG concentration from all colostrum samples submitted by the operation was used to calculate the amount of IgG fed in subsequent feedings. The total IgG fed was the sum of first and subsequent colostral feedings, if applicable.

\section{RESULTS}

This TPI analysis represented 2,360 heifer calves on 103 operations. The original data set included 2,545 dairy heifer calves from 104 operations. A total of 185 calves were removed from the analysis for the following reasons: calves fed colostrum replacer or colostrum supplement $(\mathrm{n}=30)$, blood was collected at $<24 \mathrm{~h}$ of birth and serum IgG $<1 \mathrm{~g} / \mathrm{L}(\mathrm{n}=4)$, blood was collected after $7 \mathrm{~d}$ regardless of serum IgG concentration $(\mathrm{n}=34)$, no reported serum IgG concentration $(\mathrm{n}=$ $45)$, total protein concentration $>11 \mathrm{~g} / \mathrm{dL}(\mathrm{n}=9)$, Brix score $>15 \%(\mathrm{n}=4)$, and no reported weaning date or were lost to follow-up $(\mathrm{n}=59)$. No weaning data were reported for one operation, bringing the total number of operations to 103.

Reported morbidity and mortality during the preweaning period were $34.3 \%(\mathrm{n}=809)$ and $3.2 \%(\mathrm{n}=$ 75 ), respectively. Mean age at the time of blood collection was $2.9 \mathrm{~d}(\mathrm{SD}=1.5 \mathrm{~d})$. The number and percent of calves included in each category of the 4 options are presented in Table 1. The serum IgG value category of $<10.0 \mathrm{~g} / \mathrm{L}$ included 284 of the 2,360 calves $(12.0 \%)$, whereas 1,279 calves $(54.2 \%)$ were in the category $\geq 20.0 \mathrm{~g} / \mathrm{L}$ and 838 calves $(35.5 \%)$ were in the category $\geq 25.0 \mathrm{~g} / \mathrm{L}$ of $\mathrm{IgG}$.

For the proposed standard (option 3), significant decreases in morbidity events between $<10.0 \mathrm{~g} / \mathrm{L} \mathrm{IgG}$ versus 10.0 to $17.9 \mathrm{~g} / \mathrm{L}(P=0.003)$, and 18.0 to $24.9 \mathrm{~g} / \mathrm{L}$ versus $>25.0 \mathrm{~g} / \mathrm{L}(P=0.012$; Table 2$)$ were observed based on the Bonferroni-corrected chi square $P$-value. However, no difference was observed in morbidity of calves with a serum IgG concentration of 10.0 to 17.9 $\mathrm{g} / \mathrm{L}$ versus 18.0 to $24.9 \mathrm{~g} / \mathrm{L}(P=0.614$; Table 2$)$. Heifer calf mortality was significantly lower for calves with serum IgG concentrations of 18.0 to $24.9 \mathrm{~g} / \mathrm{L}$ versus 10.0 to $17.9 \mathrm{~g} / \mathrm{L}(P=0.011$; Table 3$)$. There were no differences in percentage of mortality in calves with serum IgG concentrations of 10.0 to $17.9 \mathrm{~g} / \mathrm{L}$ versus $<10 \mathrm{~g} / \mathrm{L}(P=0.020), 18.0$ to $24.9 \mathrm{~g} / \mathrm{L}$ versus $>25 \mathrm{~g} / \mathrm{L}$ $(P=0.178$; Table 3$)$.

The authors propose option 3 with the following descriptions and serum IgG categories: excellent TPI $(\geq 25.0 \mathrm{~g} / \mathrm{L}$ serum IgG concentration), good TPI $(18.0-24.9 \mathrm{~g} / \mathrm{L})$, fair TPI $(10.0-17.9 \mathrm{~g} / \mathrm{L})$, and poor TPI $(<10.0 \mathrm{~g} / \mathrm{L})$. Serum total protein level and serum Brix scores were modeled with serum IgG to develop the comparable categories reported in Table $4\left(\mathrm{R}^{2}=\right.$ 0.803 and $R^{2}=0.797$, respectively). The percentages of calves in the NAHMS study in each consensus category are provided in Table 4 and show that across all herds, the percentages in each category are not far below the recommendations.

The model predicted morbidity and mortality percentages within each of the proposed option categories are reported in Table 5 and shown in Figure 2. The actual percentage of calves for each proposed serum IgG concentration, serum total protein, and serum 

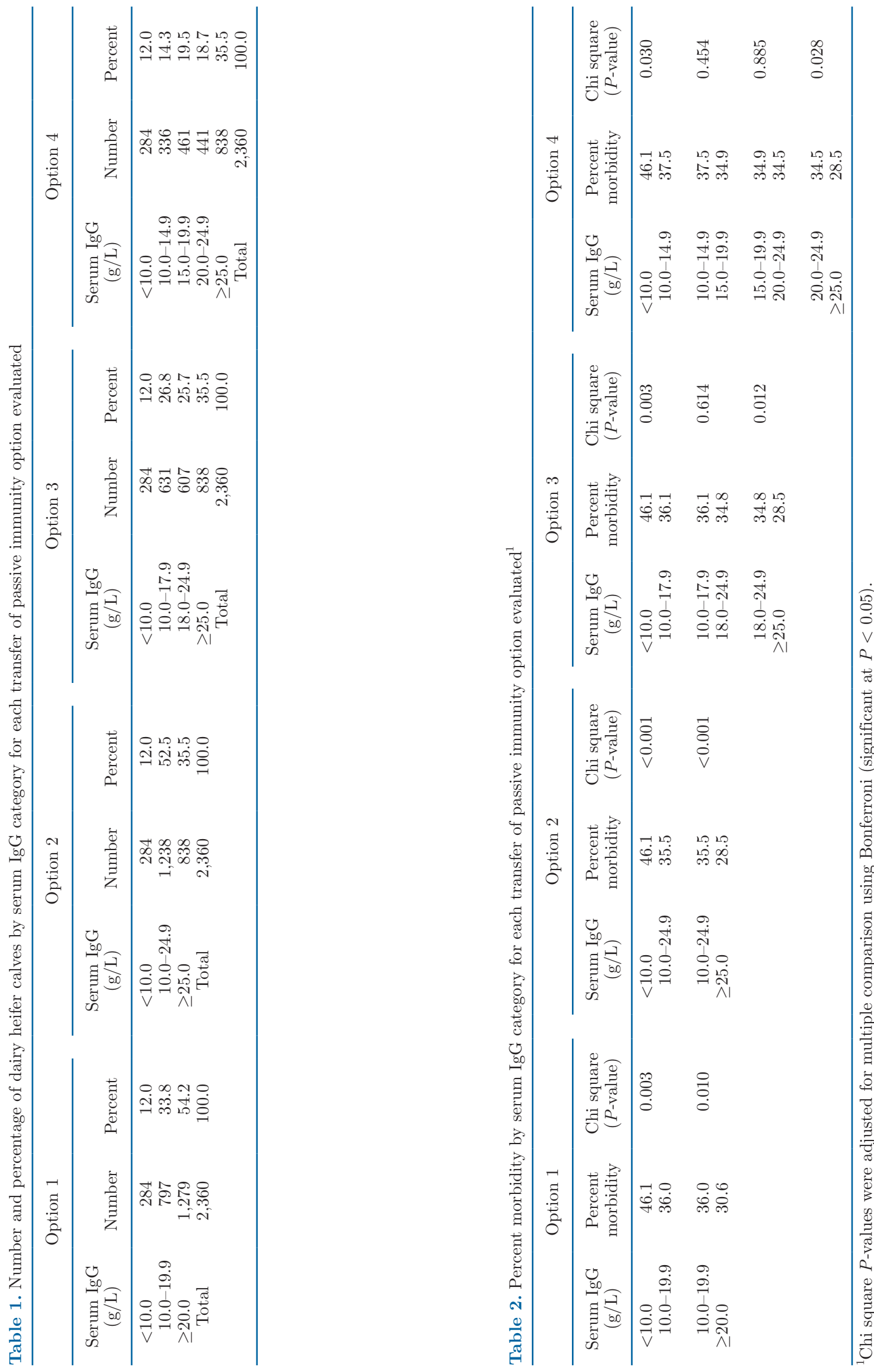

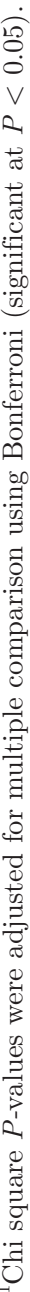




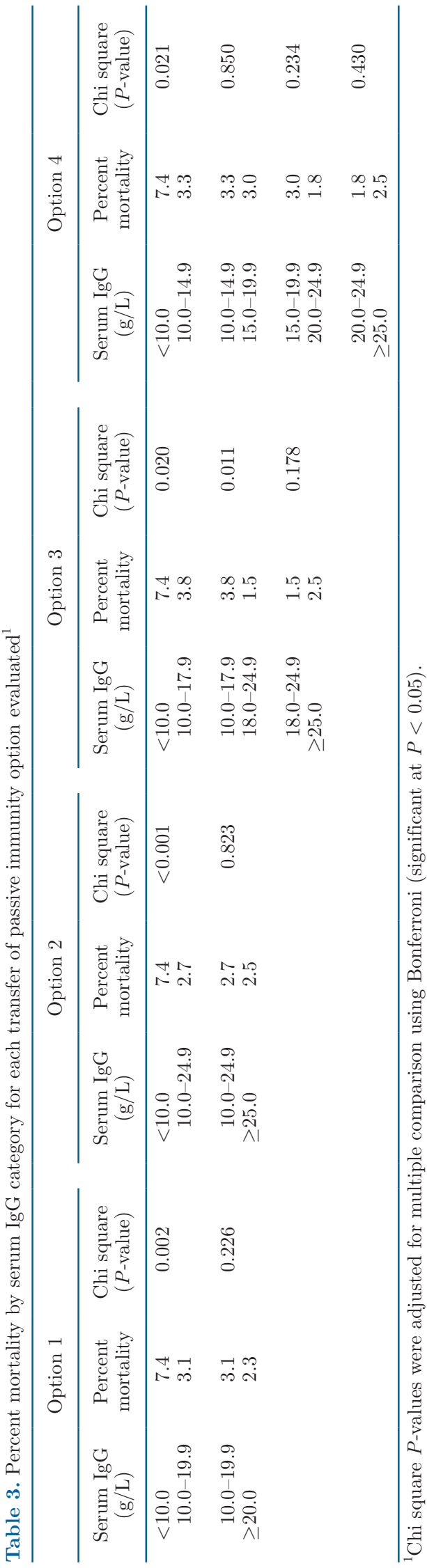

Brix $\%$ are reported for all calves in the study along with the percent morbidity and mortality in Table 6 . The model-predicted morbidity percentage follows the actual predicted percentages rather closely and shows that the higher the serum IgG concentration, the lower the percentage of disease. However, the model-predicted mortality percentages overestimate percentage of deaths compared with the actual mortality percentage. The slope of the predicted morbidity line suggests that more serum IgG is associated with less morbidity and is steeper than the slope of the predicted mortality line. The actual mortality line is fairly flat after serum IgG concentrations exceed $10 \mathrm{~g} / \mathrm{L}$, supporting the current standard for mortality.

Kaplan-Meier survival curves for nondiseased probability and survival probability for the proposed serum IgG categories are presented in Figures 3 and 4, respectively. In the nondiseased probability curves, the curves are similar over the first $7 \mathrm{~d}$ but differences begin to be observed by $10 \mathrm{~d}$ of age. Differences between the excellent and poor categories become more pronounced through $60 \mathrm{~d}$ of age. As presented in Table 2, there are no differences between the categories good and fair, which is also observed in Figure 3. Survival probability showed no differences in mortality among the categories until 7 to $10 \mathrm{~d}$ of age. As presented in Table 3, no mortality differences are present between the excellent and good categories, whereas a higher percentage of calves in the fair and poor categories died in the first $60 \mathrm{~d}$ of life.

After evaluation of the data and option 3 was selected by the authors, a Bayesian change point analysis was conducted. The posterior distribution probabilities of the change points were serum IgG concentrations of 9 to $12 \mathrm{~g} / \mathrm{L}$ and $25 \mathrm{~g} / \mathrm{L}$ for morbidity and 10, 17, and $22 \mathrm{~g} / \mathrm{L}$ for mortality. The change point probabilities for morbidity and mortality are shown in Figure 5. The change points that fell above the 80th percentile of the posterior probabilities were evaluated to choose serum IgG levels at which morbidity and mortality rates likely undergo a change. This provides additional statistical evidence that option 3 offers a reasonable balance between splitting the difference between the data-driven methods based on morbidity and mortality, expert elicitation, and a certain amount of reasonable chunking required to make the change points simple and easy to remember by producers.

To determine a herd-level standard, the NAHMS TPI data set was considered a single herd and the proportion of calves in each of the 4 calf-level categories was calculated. Based on the percentage of calves in each category, the authors debated that producers can improve TPI so the recommended herd-level standard is slightly above the current proportion for all calves 
Table 4. Consensus serum IgG concentrations and equivalent total protein (TP) and Brix measurements, and percentage of calves recommended in each transfer of passive immunity (TPI) category ${ }^{1}$

\begin{tabular}{lccccc}
\hline TPI category & $\begin{array}{c}\text { Serum IgG category } \\
(\mathrm{g} / \mathrm{L})\end{array}$ & $\begin{array}{c}\text { Equivalent } \\
\mathrm{TP}(\mathrm{g} / \mathrm{dL})\end{array}$ & $\begin{array}{c}\text { Equivalent } \\
\text { \%Brix }\end{array}$ & $\begin{array}{c}\text { Consensus }^{2} \\
(\% \text { calves })\end{array}$ & $\begin{array}{c}\text { NAHMS study }^{3} \\
(\% \text { calves })\end{array}$ \\
\hline Excellent & $\geq 25.0$ & $\geq 6.2$ & $\geq 9.4$ & $>40$ & 35.5 \\
Good & $18.0-24.9$ & $5.8-6.1$ & $8.9-9.3$ & $\sim 30$ & 2.7 \\
Fair & $10.0-17.9$ & $5.1-5.7$ & $8.1-8.8$ & $<.8$ & 20 \\
Poor & $<10.0$ & $<5.1$ & $<8.1$ & $<10$ & 12.0 \\
\hline
\end{tabular}

${ }^{1}$ Modified from Godden et al. (2019).

${ }^{2}$ Consensus recommendation for percent of a farm's calves in each category.

${ }^{3}$ Percent of calves in National Animal Health Monitoring System (NAHMS) 2014 Dairy study (Shivley et al., 2018) in each consensus category.

in the study. The proposed herd-level standard for the percent of calves in each category are: excellent $>40 \%$, good $\sim 30 \%$, fair $\sim 20 \%$, and poor $<10 \%$ of calves. An evaluation of the NAHMS TPI data set showed that $32 \%$ of participating herds $(33 / 103)$ were meeting the recommended standard in 2014-2015. This provides evidence that the herd level recommendations are realistic and achievable in US dairy herds.

\section{DISCUSSION}

Standards for attaining farm level TPI are important for helping establish management goals for farmers, veterinarians, and dairy professionals. Educational programs utilizing targets for TPI can improve outcomes at the herd level (Williams et al., 2014). It is commonly recognized that freedom from disease and death is multi-faceted and includes not only concentration of serum $\operatorname{IgG}$, but also innate immune competence, adequate nutrition, lack of stress, adequate housing, limited exposure to potential pathogens, and subjective issue of the skills and management intensity of the calf caregiver(s). Thus, standards for TPI may, in fact, be farm specific; however, industry standards provide guidelines consistent with epidemiological data on morbidity and mortality and provide reasonable targets for farmers. Reducing morbidity as an added goal through increased TPI has many advantages, not the least of which is a reduction in antimicrobial use and signifi-

Table 5. Model predicted morbidity and mortality at specified serum IgG concentrations representing categories for option 3 for calves in the National Animal Health Monitoring System Dairy 2014 study

\begin{tabular}{lcc}
\hline & \multicolumn{2}{c}{$\begin{array}{c}\text { Model predicted, } \\
\text { percent }(95 \% \mathrm{CI})\end{array}$} \\
\cline { 2 - 3 } $\begin{array}{l}\text { IgG level } \\
(\mathrm{g} / \mathrm{L})\end{array}$ & Morbidity & Mortality \\
\hline 8.0 & $41.3(34.6-48.8)$ & $8.2(6.2-10.7)$ \\
14.0 & $37.8(31.8-44.3)$ & $6.6(5.3-8.2)$ \\
21.5 & $33.6(28.2-39.5)$ & $5.0(4.1-6.2)$ \\
27.0 & $30.6(25.2-36.6)$ & $4.1(3.1-5.4)$ \\
\hline
\end{tabular}

cantly greater lifetime production levels (Heinrichs and Heinrichs, 2011).

However, the existing dichotomous standard seems too simplistic to fully reflect the effect of $\operatorname{IgG}$ concentration, particularly regarding calf morbidity. For example, considering 2 calves, one with a serum IgG concentration of $9.8 \mathrm{~g} / \mathrm{L}$ and the other with 10.2 $\mathrm{g} / \mathrm{L}$, the first calf is considered to be at greater risk of disease whereas the second would be at less risk. The small difference in serum IgG concentration placed these calves in different risk categories when there was likely very little or no difference in risk. As an alternative example, the current dichotomous standard suggests that 2 calves with serum IgG concentrations of 10.5 and $20 \mathrm{~g} / \mathrm{L}$ are similarly well protected against risk of disease, although data show that the calf with the higher level of TPI is less likely to develop disease. Multiple categories may more accurately place calves in categories consistent with the risk on the farm.

We recommend transitioning from the current standard with 2 categories (FPI, SPI) to one with 4 categories (excellent, good, fair, and poor) representing $\geq 25.0$, 18.0 to $24.9,10.0$ to 17.9 , and $<10.0 \mathrm{~g}$ of serum $\operatorname{IgG} / \mathrm{L}$, respectively. We assume that serum IgG is measured at approximately 24 to $48 \mathrm{~h}$ after birth. Equivalent serum total protein and serum Brix values are also provided for convenience since these methods are more commonly used on-farm to measure TPI in calves (USDA, 2016). The proposed standard was based on data from dairy heifer calves but should be applied to both dairy bull and heifer calves.

Other research supports our recommendation to refine and revise TPI categories. For example, FurmanFratczak et al. (2011), included 175 dairy heifer calves born on a single operation during a 1-yr period. Calves were grouped into 4 groups based on serum immunoglobulin concentrations at 30 to $60 \mathrm{~h}$ of life $(<5$, 5 to 10,10 to 15 , and $>15 \mathrm{~g} / \mathrm{L})$. The morbidity and intensity of disease course were lowest in heifer calves with serum immunoglobulin concentrations exceeding $10 \mathrm{~g} / \mathrm{L}$; these calves did not become ill before d 14 of 


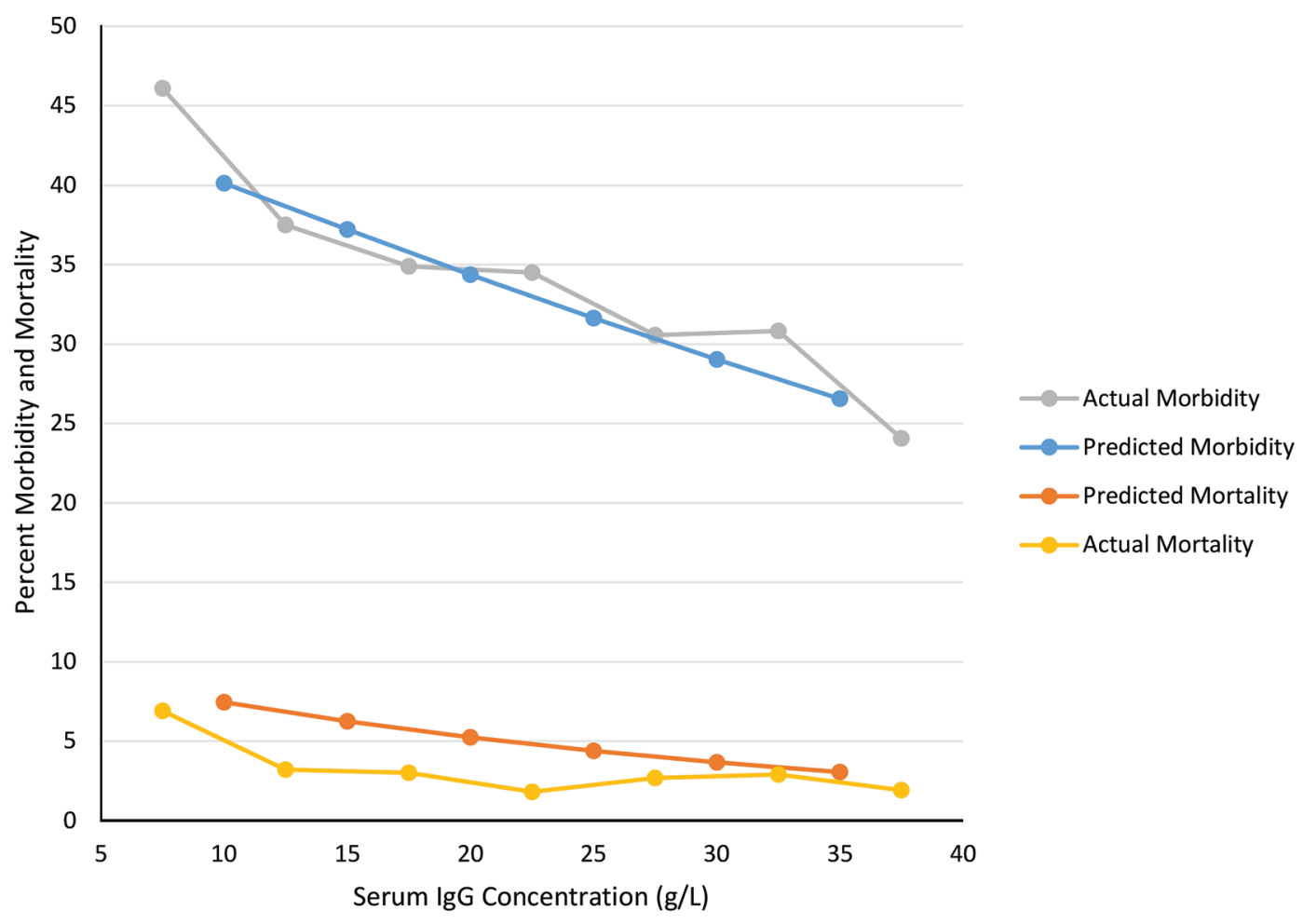

Figure 2. Model predicted and actual percent morbidity and mortality by serum IgG concentration for preweaned dairy heifer calves in the National Animal Health Monitoring System (NAHMS) Dairy 2014 study (n = 2,360; Urie et al., 2018b).

life, whereas calves with serum $\operatorname{IgG}>15 \mathrm{~g} / \mathrm{L}$ avoided respiratory tract infections.

Chigerwe et al. (2015) evaluated 1,290 dairy heifer calves on a calf raising facility from 48 farms and calves were stratified based on serum IgG concentrations at 2 $\mathrm{d}$ of age $(\leq 15,15.01$ to $20.0,20.01$ to 25.0 , and $>25.0$ $\mathrm{g} / \mathrm{L})$. In contrast to other studies that showed the current standard of $10 \mathrm{~g} / \mathrm{L}$ IgG being acceptable for mortality, serum IgG concentrations of 20.01 to $25.0 \mathrm{~g} / \mathrm{L}$ and total protein concentrations of 5.8 to $6.3 \mathrm{~g} / \mathrm{dL}$ better indicated adequate TPI in dairy calves. The authors stated that serum IgG concentrations $>20$ to $25 \mathrm{~g} / \mathrm{L}$ were of little practical benefit because protection from morbidity and mortality plateau at this concentration.

Waldner and Rosengren (2009) evaluated effects of serum IgG concentrations and disease events in 601 beef calves sampled between 2 and 8 d of age. Odds of mortality and morbidity in the first 3 mo of life were

Table 6. Number and percentage of heifer calves and calf morbidity and mortality by consensus category of serum IgG and total protein concentration, and Brix percentage for calves in the National Animal Health Monitoring System Dairy 2014 study

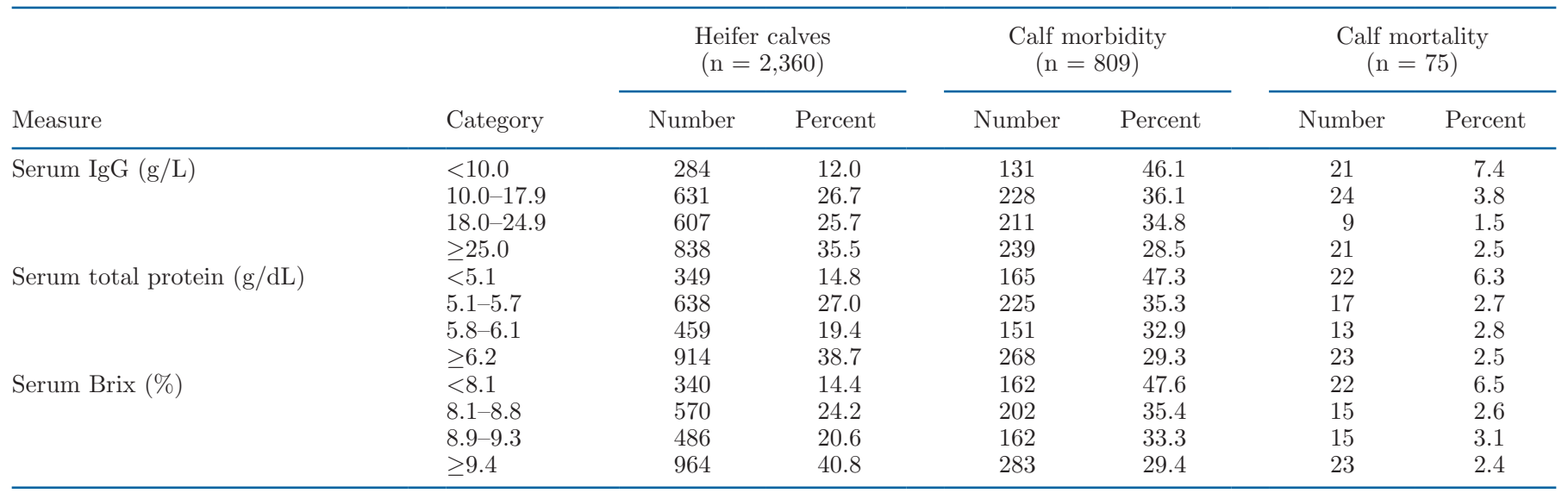


increased in calves when serum IgG concentrations $<24$ g/L. Waldner and Rosengren (2009, p. 280) stated, "Our findings directly contradict recommendations that dairy producers only aim for serum total protein levels above $50 \mathrm{~g} / \mathrm{L}[5.0 \mathrm{~g} / \mathrm{dL}]$ (roughly equivalent to serum IgG levels $>10 \mathrm{~g} / \mathrm{L}$ ), because this is reasonable and attainable. Instead, beef producers should aim to maximize passive transfer and optimize the protective health benefits of colostrum."

The NAHMS Dairy studies have provided a snapshot of dairy practices related to calf management and estimates of TPI status since the early 1990s (USDA, 1994, 2018). The Dairy 2014 study included a longitudinal calf component that followed heifer calves from birth to weaning and collected multiple data points including colostrum management, morbidity and mortality events, feeding, housing, and growth parameters (Shivley et al., 2018; Stenkamp-Strahm et al., 2018; Urie et al., 2018a,b). Data from this study provided an opportunity to review health and TPI status, which were used to construct these recommendations. As with most field-based studies, the NAHMS Dairy 2014 study had limitations, including that it was not a controlled study, most of the data were collected by dairy personnel and not by researchers, and not all practices were captured and quantified, such as if some calves were able to suckle colostrum from their dam without it being recorded in the data.

Recommended targets for assessing TPI vary by species (Wittum and Perino, 1995; Erhard et al., 2001; Metzger et al., 2006; Woon et al., 2014), many of which diverge from the $10 \mathrm{~g}$ of serum IgG/L used in the dairy industry. Recommended targets for beef calves are higher than $10 \mathrm{~g} / \mathrm{L}$ (Wittum and Perino, 1995; Dewell et al., 2006; Waldner and Rosengren, 2009) and multiple categories have been evaluated (Wittum and Perino, 1995). Evaluation of the different proposed categories included the statistical models reported herein, but also the assessment of usability of any recommended standard. A standard that was too complex (e.g., option 4) would be difficult to implement. Standards that were too simple (e.g., option 1) fail to capture differences in risk associated with differences in serum IgG concentration. Option 3 was selected as the appropriate balance between experiences, previous studies, and statistical significance from the NAHMS study (Tables 1 and 2) and usability in the industry. The Bayesian change point analysis, done post hoc, also supports option 3 and the cutoffs are based on changes in both morbidity and mortality.

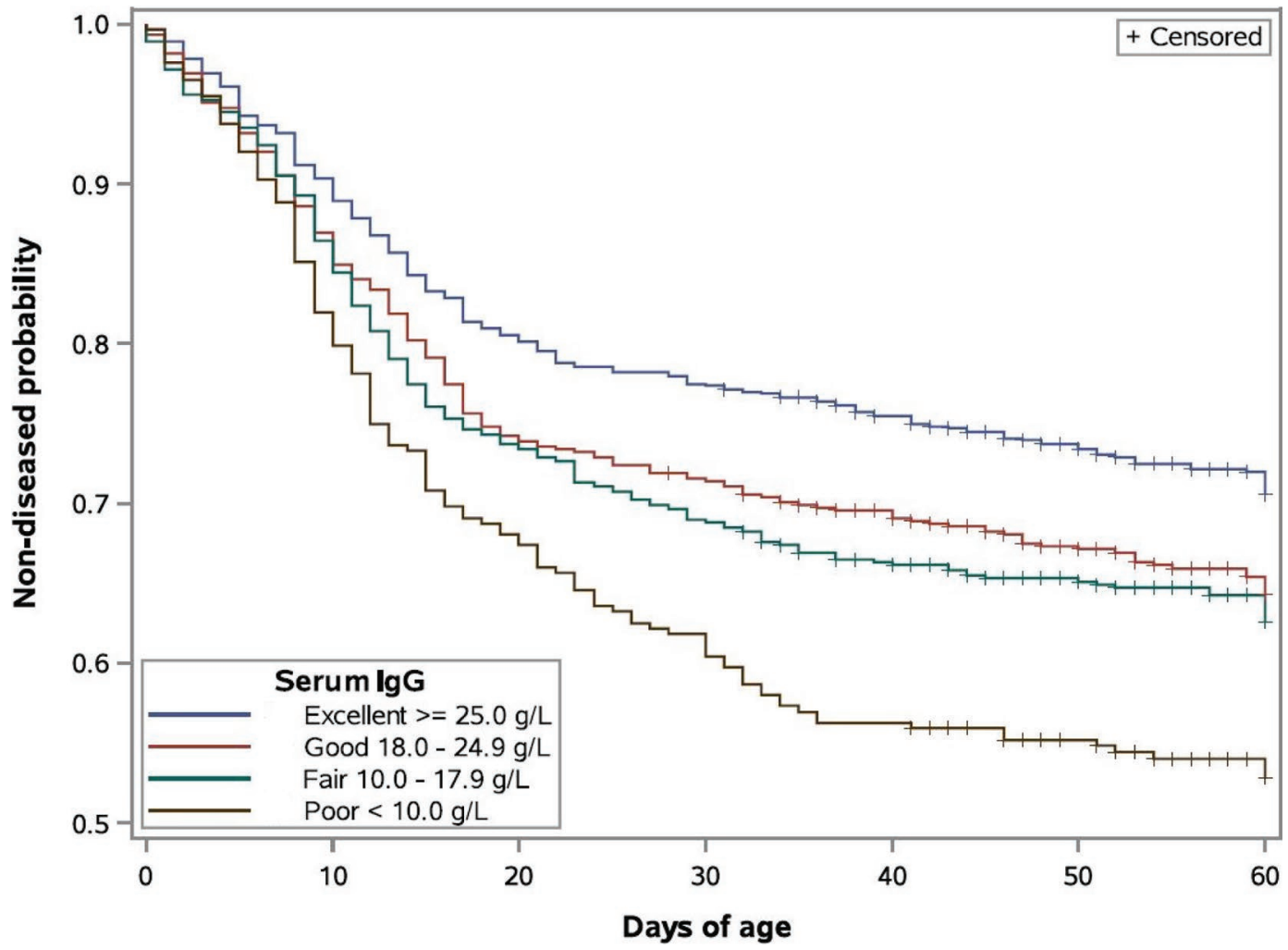

Figure 3. Non-diseased probability by serum IgG concentration for preweaned dairy heifer calves in the NAHMS Dairy 2014 study $(\mathrm{n}=$ 2,360; Urie et al., 2018b). Reprinted with permission from Godden et al. (2019). 


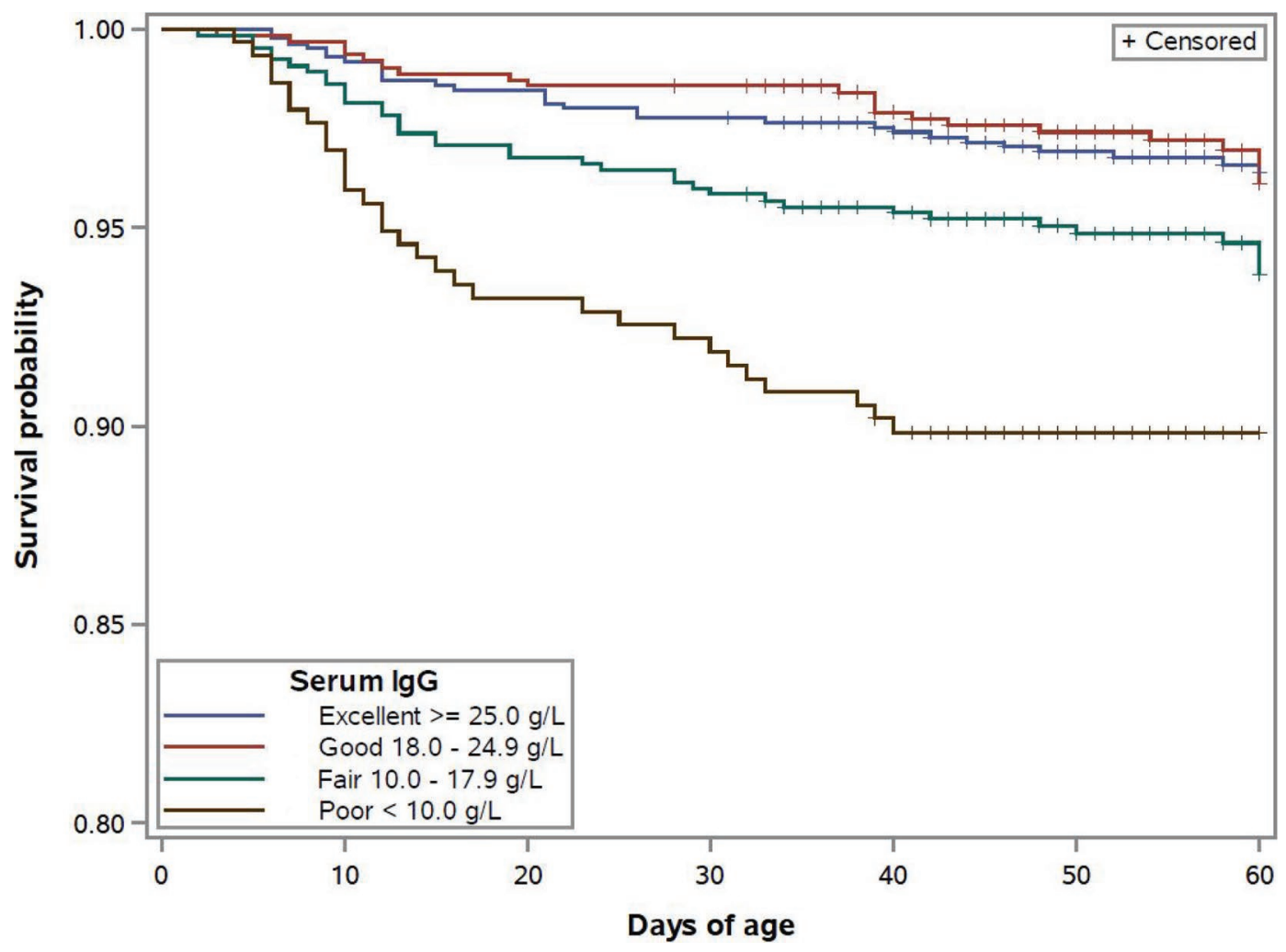

Figure 4. Survival probability by serum IgG concentration for preweaned dairy heifer calves in the National Animal Health Monitoring System (NAHMS) Dairy 2014 study (n = 2,360; Urie et al., 2018b).

One criteria that was used to determine a herd-level standard to be proposed was the feasibility of the standard being achievable. The NAHMS data confirm that the proposed standard is achievable on farms, as $32 \%$ of farms met the herd-level standard. The herd-level standard should give dairy producers and consultants consistent standards/goals that are achievable with excellent colostrum management.

After the new calf- and herd-level standards were agreed upon on by the authors, the question of revisiting the colostrum quality standard was broached. We decided that the minimum cutpoint of $50 \mathrm{~g} / \mathrm{L}$ for colostrum quality was appropriate even though the mean colostral IgG concentration for Holsteins in the United States is close to $74 \mathrm{~g} / \mathrm{L}$ (Morrill et al., 2012; Shivley et al., 2018).

Data from the NAHMS TPI data set were evaluated to estimate quantity and quality of colostrum fed and feeding times for heifer calves achieving excellent TPI. Colostrum management practices for 705 heifer calves from 90 operations in the NAHMS TPI data set that had excellent passive immunity ( $25 \mathrm{~g} / \mathrm{L}$ or more $\operatorname{IgG}$ ) were evaluated to provide feeding recommendations (Table 7). For the 251 calves fed a single feeding of colostrum, they were fed an average of $3.3 \mathrm{~L}$ at $2.0 \mathrm{~h}$ of age and received $286.7 \mathrm{~g}$ of $\mathrm{IgG}$. These calves had an average serum IgG of $32.0 \mathrm{~g} / \mathrm{L}$. For the 453 calves that were fed multiple feedings of colostrum, they were fed an average of $2.7 \mathrm{~L}$ at $2.8 \mathrm{~h}$ of age and received $226.6 \mathrm{~g}$ of IgG at the first feeding. Colostral IgG content of the second feeding was calculated as the operation average colostral IgG concentration for all samples tested since the second feeding of colostrum was not tested. The total amount of colostrum fed was $5.3 \mathrm{~L}$ with a total estimated IgG consumption of $421.2 \mathrm{~g}$. The average serum $\operatorname{IgG}$ concentration was $33.9 \mathrm{~g} / \mathrm{L}$.

We believe the recommended calf-level goals for TPI presented here are very achievable because onethird of calves in 2014 were already meeting the goal of $\geq 25 \mathrm{~g} / \mathrm{L}$ of serum IgG. Our current understanding of the process of IgG absorption suggests that achieving these levels of calf serum IgG requires provision of high-quality colostrum promptly after birth. As summarized in the paragraph above and shown in Table 7, the 704 operations in the NAHMS TPI data set that met these standards accomplished this with either a single feeding of colostrum at approximately $2 \mathrm{~h}$ after birth, delivering approximately $300 \mathrm{~g}$ of $\mathrm{IgG}$, or alternatively by feeding multiple colostrum feedings and delivering approximately $400 \mathrm{~g}$ of total $\mathrm{IgG}$ in the first 

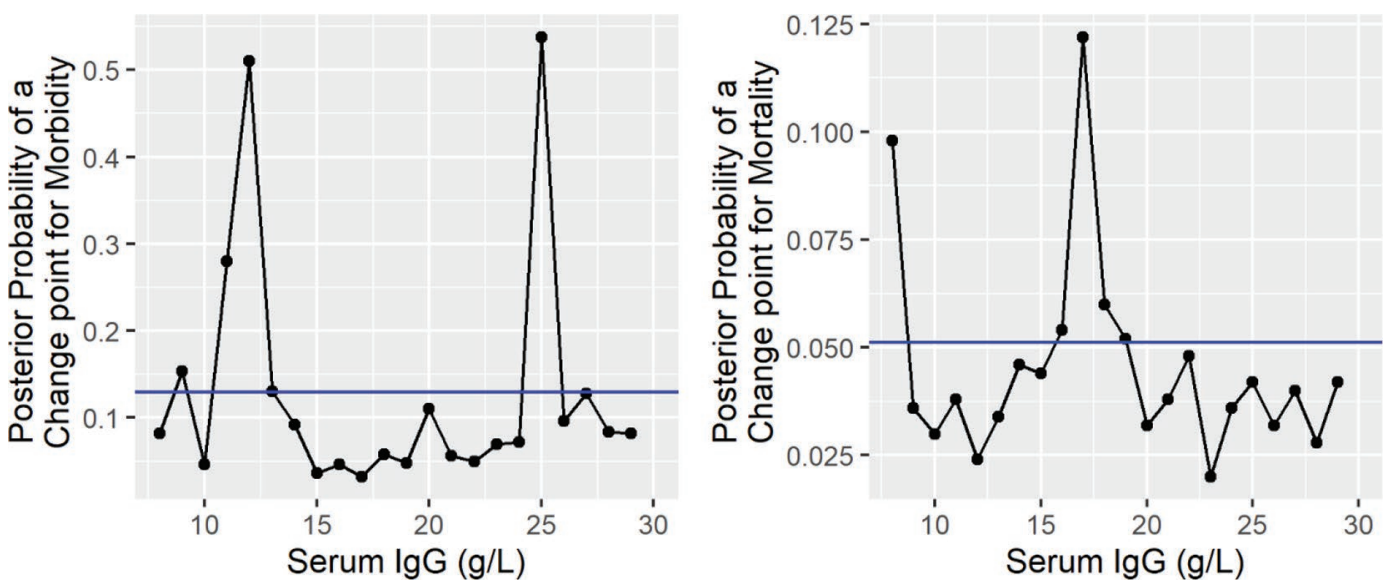

Figure 5. Posterior probability plots of a change point based on morbidity and mortality, respectively, of preweaned dairy heifer calves, by serum IgG concentration.

$24 \mathrm{~h}$. Other health performance benefits may accrue to extended colostrum feeding (Inabu et al., 2019), but are beyond the scope of the specific recommendations in this paper. These are achievable goals for operations with well-managed colostrum feeding protocols. Further study of feeding practices that optimize outcomes would be helpful in developing more specific feeding guidelines on timing and total IgG content of colostrum delivered to newborn calves.

Just as we are proposing new TPI standards based on supporting data, the standard should be reviewed periodically to determine if changes need to be made in the future. In addition, to new data, there are likely to be technological advances that may require changes to this proposed standard.

\section{CONCLUSIONS}

Serum $\operatorname{IgG}$ measured at 24 to $48 \mathrm{~h}$ of age has long been used as the gold standard measure of TPI, and in dairy calves, a threshold of $10 \mathrm{~g} / \mathrm{L}$ has been used to effectively reduce incidence of neonatal mortality in the United States. The proposed TPI standard includes 4 serum IgG categories: excellent, good, fair, and poor with serum IgG levels of $\geq 25.0,18.0-24.9,10.0-17.9$, and $<10 \mathrm{~g} / \mathrm{L}$. At the herd level, it is proposed that $>40$, 30,20 , and $<10 \%$ of calves are in the excellent, good, fair, and poor TPI categories, respectively. Implementation of the proposed standard should further reduce the risk of both mortality and morbidity in newborn calves.

\section{ACKNOWLEDGMENTS}

The authors acknowledge Karen Jordan [Siler City, $\mathrm{NC}$, chair of the Animal Health and Wellbeing Committee for the National Milk Producers Federation (NMPF)] and Jennifer Walker (Dallas, TX, director of milk quality at Danone North America) for their contribution to the expert panel and support of the consensus recommendations. The authors have no conflicts of interest.

Table 7. Descriptive statistics for colostrum management practices for calves in the National Animal Health Monitoring System transfer of passive immunity data set having excellent passive immunity ( $\geq 25 \mathrm{~g} / \mathrm{L}$ serum IgG) and fed single or multiple colostrum feedings

\begin{tabular}{|c|c|c|c|c|}
\hline \multirow[b]{2}{*}{ Measurement } & \multicolumn{2}{|c|}{$\begin{array}{l}\text { Single colostrum } \\
\text { feeding }(\mathrm{n}=251)\end{array}$} & \multicolumn{2}{|c|}{$\begin{array}{l}\text { Multiple colostrum } \\
\text { feedings }(\mathrm{n}=453)\end{array}$} \\
\hline & Mean & $\mathrm{SD}$ & Mean & $\mathrm{SD}$ \\
\hline Calf birth weight (kg) & 42.0 & 5.5 & 42.1 & 5.8 \\
\hline Volume of first colostrum feeding (L) & 3.3 & 0.8 & 2.7 & 0.9 \\
\hline First feeding colostral IgG fed (g) & 286.7 & 123.0 & 226.6 & 112.3 \\
\hline Age at first colostral feeding $(\mathrm{h})$ & 2.0 & 1.9 & 2.8 & 2.2 \\
\hline Total volume of colostrum fed in $24 \mathrm{~h}(\mathrm{~L})$ & 3.3 & 0.8 & 5.3 & 1.4 \\
\hline Total colostral IgG fed (g) & 286.7 & 123.0 & 421.2 & 137.5 \\
\hline Serum IgG $(g / L)$ & 32.0 & 5.5 & 33.9 & 8.2 \\
\hline
\end{tabular}




\section{REFERENCES}

Barry, D., and J. A. Hartigan. 1993. A Bayesian analysis for change point problems. J. Am. Stat. Assoc. 35:309-319.

Chigerwe, M., J. V. Hagey, and S. S. Aly. 2015. Determination of neonatal serum immunoglobulin G concentrations associated with mortality during the first 4 months of life in dairy heifer calves. J. Dairy Res. 82:400-406. https://doi.org/10.1017/ S0022029915000503.

Dewell, R. D., L. L. Hungerford, J. E. Keen, W. W. Laegreid, D. D. Griffin, G. P. Rupp, and D. M. Grotelueschen. 2006. Association of neonatal serum immunoglobulin G1 concentration with health and performance in beef calves. J. Am. Vet. Med. Assoc. 228:914-921. https://doi.org/10.2460/javma.228.6.914.

Erdman, C., and J. W. Emerson. 2007. Bcp: An R package for performing a Bayesian analysis of change point problems. J. Stat. Softw. 23:1-13. https://doi.org/10.18637/jss.v023.i03 https:// www.jstatsoft.org/article/view/v023i03/v23i03.pdf.

Erhard, M. H., C. Luft, H.-P. Remler, and M. Stangassinger. 2001. Assessment of colostral transfer and systemic availability of immunoglobulin $\mathrm{G}$ in new-born foals using a newly developed enzymelinked immunosorbent assay (ELISA) system. J. Anim. Physiol. Anim. Nutr. (Berl.) 85:164-173. https://doi.org/10.1046/j.1439 $-0396.2001 .00313 . x$.

Furman-Fratczak, K., A. Rzasa, and T. Stefaniak. 2011. The influence of colostral immunoglobulin concentration in heifer calves' serum on their health and growth. J. Dairy Sci. 94:5536-5543. https:// doi.org/10.3168/jds.2010-3253.

Gay, C. C. 1983. Failure of passive transfer of colostral immunoglobulins and neonatal disease in calves: A review. Pages 346-364 in Proc. 4th Int. Symp. Neonatal Dis. Vet. Infect. Dis. Org., Saskatoon, SK, Canada.

Godden, S. M., J. E. Lombard, and A. R. Woolums. 2019. Colostrum management for dairy calves. Vet. Clin. North Am. Food Anim. Pract. 35:535-556. https://doi.org/10.1016/j.cvfa.2019.07.005.

Heinrichs, A. J., and B. S. Heinrichs. 2011. A prospective study of calf factors affecting first-lactation and lifetime milk production and age of cows when removed from the herd. J. Dairy Sci. 94:336-341. https://doi.org/10.3168/jds.2010-3170.

Hosmer, D. W., and S. Lemeshow. 1999. Applied Survival Analysis: Regression Modeling of Time to Event Data. John Wiley \& Son Inc., New York, NY.

Inabu, Y., J. Pyo, S. Pletts, L. L. Guan, M. A. Steele, and T. Sugino. 2019. Effect of extended colostrum feeding on plasma glucagon-like peptide-1 concentration in newborn calves. J. Dairy Sci. 102:46194627. https://doi.org/10.3168/jds.2018-15616.

McGuirk, S. M. 2005. Herd based testing for young stock. Pages 146148 in Proc. 38th Annu. Conf. AABP.

Metzger, N., K. W. Hinchcliff, J. Hardy, C. C. Schwarzwald, and T. Wittum. 2006. Usefulness of a commercial equine IgG test and serum protein concentration as indicators of failure of transfer of passive immunity in hospitalized foals. J. Vet. Intern. Med. 20:382-387. https://doi.org/10.1111/j.1939-1676.2006.tb02872.x.

Morrill, K. M., E. Conrad, A. Lago, J. Campbell, J. Quigley, and H. Tyler. 2012. Nationwide evaluation of quality and composition of colostrum on dairy farms in the United States. J. Dairy Sci. 95:3997-4005. https://doi.org/10.3168/jds.2011-5174.

Peter, A. T. 2013. Bovine placenta: A review on morphology, components, and defects from terminology and clinical perspectives. Theriogenology 80:693-705. https://doi.org/10.1016/j.theriogenology 2013.06.004

Renaud, D. L., K. M. Waalderbos, L. Beavers, T. F. Duffield, K. E. Leslie, and M. C. Windeyer. 2020. Risk factors associated with failed transfer of passive immunity in male and female dairy calves: A 2008 retrospective cross-sectional study. J. Dairy Sci. 103:35213528. https://doi.org/10.3168/jds.2019-17397.

Shaffer, J. P. 1995. Multiple hypothesis testing. Annu. Rev. Psychol. 46:561-584. https://doi.org/10.1146/annurev.ps.46.020195 .003021 .

Shivley, C. B., J. E. Lombard, N. J. Urie, D. M. Haines, R. Sargent, C. A. Kopral, T. J. Earleywine, J. D. Olson, and F. B. Garry.
2018. Preweaned heifer management on US dairy operations: Part II. Factors associated with colostrum quality and passive transfer status of dairy heifer calves. J. Dairy Sci. 101:9185-9198. https:// doi.org/10.3168/jds.2017-14008.

Shivley, C. B., J. E. Lombard, N. J. Urie, D. M. Weary, and M. A. G. von Keyserlingk. 2019. Management of preweaned bull calves on dairy operations in the United States. J. Dairy Sci. 102:4489-4497. https://doi.org/10.3168/jds.2018-15100.

Stenkamp-Strahm, C., J. E. Lombard, R. J. Magnuson, L. M. Linke, S. Magzamen, N. J. Urie, C. B. Shivley, and C. S. McConnel. 2018. Preweaned heifer management on US dairy operations: Part IV. Factors associated with the presence of Escherichia coli $\mathrm{O} 157$ in preweaned dairy heifers. J. Dairy Sci. 101:9214-9228. https://doi .org/10.3168/jds.2018-14659.

Todd, C. G., M. McGee, K. Tiernan, P. Crosson, E. O'Riordan, J. McClure, I. Lorenz, and B. Earley. 2018. An observational study on passive immunity in Irish suckler beef and dairy calves: Tests for failure of passive transfer of immunity and associations with health and performance. Prev. Vet. Med. 159:182-195. https://doi.org/10 .1016/j.prevetmed.2018.07.014.

Urie, N. J., J. E. Lombard, C. B. Shivley, C. A. Kopral, A. E. Adams, T. J. Earleywine, J. D. Olson, and F. B. Garry. 2018a. Preweaned heifer management on US dairy operations: Part I. Descriptive characteristics of preweaned heifer raising practices. J. Dairy Sci. 101:9168-9184. https://doi.org/10.3168/jds.2017-14010.

Urie, N. J., J. E. Lombard, C. B. Shivley, C. A. Kopral, A. E. Adams, T. J. Earleywine, J. D. Olson, and F. B. Garry. 2018b. Preweaned heifer management on US dairy operations: Part V. Factors associated with morbidity and mortality in preweaned dairy heifer calves. J. Dairy Sci. 101:9229-9244. https://doi.org/10.3168/jds .2017-14019.

USDA. 1993. Transfer of maternal immunity to calves. National Dairy Heifer Evaluation Project. USDA-Animal and Plant Health Inspection Service (APHIS)-Veterinary Services (VS)-Center for Epidemiology and Animal Health (CEAH), Fort Collins, CO. Accessed Feb. 12, 2020. https://www.aphis.usda.gov/animal_health/ nahms/dairy/downloads/ndhep/NDHEP_Immunity.pdf.

USDA. 1994. Dairy heifer morbidity, mortality, and health management focusing on preweaned heifers. US Department of Agriculture, National Animal Health Monitoring System (NAHMS). Accessed Feb. 12, 2020. https://www.aphis.usda.gov/animal_health/ nahms/dairy/downloads/ndhep/NDHEP_dr_Report.pdf.

USDA. 1996. Dairy 1996, Part I: Reference of 1996 dairy management practices. US Department of Agriculture, National Animal Health Monitoring System (NAHMS). Accessed Feb. 12, 2020. https:// www.aphis.usda.gov/animal_health/nahms/dairy/downloads/ dairy96/Dairy96_dr_PartI.pdf.

USDA. 2008. Beef 2007-08, Part I: Reference of Beef Cow-calf Management Practices in the United States, 2007-08. USDA-Animal and Plant Health Inspection Service (APHIS)-Veterinary Services (VS)-Center for Epidemiology and Animal Health (CEAH), Fort Collins, CO. Accessed Feb. 12, 2020. https://www.aphis.usda.gov/ animal_health/nahms/beefcowcalf/downloads/beef0708/Beef0708 _dr_PartI_rev_1.pdf.

USDA. 2010. Beef 2007-08, Part IV: Reference of Beef Cow-calf Management Practices in the United States, 2007-08. USDA-Animal and Plant Health Inspection Service (APHIS)-Veterinary Services (VS)-Center for Epidemiology and Animal Health (CEAH), Fort Collins, CO. Accessed Feb. 12, 2020. https://www.aphis.usda.gov/ animal_health/nahms/beefcowcalf/downloads/beef0708/Beef0708 _dr_PartIV_1.pdf.

USDA. 2016. Dairy 2014: Dairy cattle management practices in the United States, 2014. USDA-Animal and Plant Health Inspection Service (APHIS)-Veterinary Services (VS)-Center for Epidemiology and Animal Health (CEAH), Fort Collins, CO. Accessed Feb. 12, 2020. https://www.aphis.usda.gov/animal_health/nahms/ dairy/downloads/dairy14/Dairy14_dr_PartI_1.pdf.

USDA. 2018. Dairy 2014: Health and management practices on U.S. dairy operations, 2014. USDA-Animal and Plant Health Inspection Service (APHIS)-Veterinary Services (VS)-Center for Epidemiology and Animal Health (CEAH), Fort Collins, CO. Ac- 
cessed May 24, 2019. https://www.aphis.usda.gov/animal_health/ nahms/dairy/downloads/dairy14/Dairy14_dr_PartIII.pdf.

Waldner, C. L., and L. B. Rosengren. 2009. Factors associated with serum immunoglobulin levels in beef calves from Alberta and Saskatchewan and association between passive transfer and health outcomes. Can. Vet. J. 50:275-281.

Weaver, D. M., J. W. Tyler, D. C. VanMetre, D. E. Hostetler, and G. M. Barrington. 2000. Passive transfer of colostral immunoglobulins in calves. J. Vet. Intern. Med. 14:569-577. https://doi.org/10 $.1111 /$ j.1939-1676.2000.tb02278.x.

Wells, S. J., D. A. Dargatz, and S. L. Ott. 1996. Factors associated with mortality to 21 days of life in dairy heifers in the United States. Prev. Vet. Med. 29:9-19. https://doi.org/10.1016/S0167 $-5877(96) 01061-6$

Williams, D. R., P. Pithua, A. Garcia, J. Champagne, D. M. Haines, and S. S. Aly. 2014. Effect of three colostrum diets on passive transfer of immunity and preweaning health in calves on a California dairy following colostrum management training. Vet. Med. Intern. 2014:698741. https://doi.org/10.1155/2014/698741.

Windeyer, M. C., K. E. Leslie, S. M. Godden, D. C. Hodgins, K. D. Lissemore, and S. J. LeBlanc. 2014. Factors associated with morbidity, mortality, and growth of dairy heifer calves up to 3 months of age. Prev. Vet. Med. 113:231-240. https://doi.org/10.1016/j .prevetmed.2013.10.019.
Wittum, T. E., and L. J. Perino. 1995. Passive immune status at postpartum hour 24 and long-term health and performance of calves. Am. J. Vet. Res. 56:1149-1154.

Woon, S. Y., M. D. Barton, and T. Vanniasinkam. 2014. Effect of plasma transfer on survival rates of low-birth-weight neonatal piglets. J. Swine Health Prod. 22:197-200.

\section{ORCIDS}

J. Lombard (ํ) https://orcid.org/0000-0003-4465-4797

N. Urie (ㄱ https://orcid.org/0000-0001-5207-6494

F. Garry (ㄴ) https://orcid.org/0000-0002-8018-713X

S. Godden $\odot$ https://orcid.org/0000-0002-4438-0039

J. Quigley ๑ https://orcid.org/0000-0001-8400-8963

T. Earleywine (i) https://orcid.org/0000-0002-9880-4626

D. Moore ๑ https://orcid.org/0000-0002-5288-7307

M. Branan $\odot$ https://orcid.org/0000-0002-3433-4338

G. Smith (1) https://orcid.org/0000-0001-5700-8810

A. J. Heinrichs @ https://orcid.org/0000-0001-5217-473X

J. Maas ํㅏ https://orcid.org/0000-0002-5662-3704 